\title{
HUBUNGAN USIA PERTAMA KALI BERHUBUNGAN SEKSUAL DENGAN KEJADIAN IVA POSITIF PADA WANITA YANG MELAKUKAN DETEKSI DINI MENGGUNAKAN METODE INSPEKSI VISUAL DENGAN ASAM ASETAT (IVA) DI WILAYAH KERJA LAYANAN KESEHATAN CUMA-CUMA (LKC) DOMPET DHUAFA
}

\author{
*Uswatun Hasanah, **Ratna Djuwita \\ Program Studi S1 Keperawatan, STIKes Widya Dharma Husada Tangerang \\ Jalan Pajajaran No1, Pamulang Tangerang Selatan Banten \\ uswatunhasanah@wdh.ac.id
}

\begin{abstract}
ABSTRAK
Kanker leher rahim merupakan kanker nomer dua terbanyak diderita oleh perempuan di seluruh dunia dan penyebab kematian akibat kanker yang paling utama, khususnya bagi perempuan di negara-negara berkembang (WHO, 2002). prevalensi kanker leher rahim di wilayah DKI Jakarta sebesar 1,2 dari 5.919 wanita yang melakukan skrining dan Provinsi Jawa Barat sebesar 0,7 dari 15.635 wanita. Sebelum terjadinya kanker leher rahim akan didahului dengan keadaan yang disebut lesi prakanker. Prevalansi lesi prakanker leher rahim tahun 2012 sebesar 4,5\%. Salah satu faktor resiko lesi prakanker leher rahim yaitu usia pertama kali berhubungan seksual $<17$ tahun yang saat ini masih tinggi di masyarakat. Penelitian ini bertujuan untuk mengetahui hubungan usia pertama kali berhubungan seksual dengan kajadian lesi prakanker leher rahim pada wanita yang melakukan skrining dengan metode Inspeksi Visual Asam Asetat (IVA) di Wilayah kerja Layanan Kesehatan Cuma-Cuma Dompet Dhuafa pada tahun. Penelitian dilakukan dengan desain kasus kontrol, menggunakan data sekunder rekam medis pemeriksaan kanker leher rahim dan kanker payudara pada tahun 2016 dengan jumlah sampel 230 yang terdiri dari 46 kasus dan 184 kontrol. Subjek penelitian adalah penerima manfaat yang kurang mampu di 2 wilayah kerja Layanan Kesehatan Cuma-Cuma (LKC) Dompet Dhuafa yaitu Depok dan Jakarta Utara. Hasil penelitian menunjukkkan bahwa usia pertama kali berhubungan seksual $<17$ tahun memiliki hubungan yang signifikan dengan nilai OR: 4,092, 95\% CI (CI,1,769-9,464) artinya wainta yang memulai hubungan seksual < 17 tahun memiliki resiko 4,092 kali untuk mengalami kejadian lesi prakanker leher rahim dibandingkan pada wainta yang memulai hubungan seksual $\geq 17$ tahun setelah dikontrol variabel paritas dan KB Hormonal $>5$ tahun. Oleh karenanya peningkatan pengetahuan dan pemahaman tentang faktor resiko kanker leher rahim melalui edukasi, pendewasaan usia pernikahan serta deteksi dini melalui pemeriksaan rutin akan membantu mengurangi kasus lesi prakanker leher rahim.
\end{abstract}

Kata Kunci: Kanker Leher Rahim, Inspeksi Visual Asam Asetat (IVA) Positif

\begin{abstract}
Cervical cancer is second most common worldwide cancer afflict to women and leading cause of cancer deaths, particularly for women in developing countries (WHO, 2002). The prevalence of cervical cancer in women who has been screening in Jakarta around 1,2 from 5,919 and around 0.7 out of 15,635 in West Java. The diagnosis of cervical cancer will be preceded by a condition called pre-cancerous lesions. Prevalence of pre-cancerous cervical lesions in 2012 is $4.5 \%$. One of the risk factors of pre-cancerous cervical lesions is age less than $<17$ years of first sexual intercourse which is still high in society. This study explained relationship between firsttime sexual intercourse with the occurrence of cervical pre-cancer lesions in female beneficiaries doing early detection using Visual Acetic Acid Inspection (IVA) at Layanan Kesehatan Cuma-Cuma Dompet Dhuafa on 2016. The study was conducted with case control design, using secondary data of medical record of cervical cancer and breast cancer in 2016 with 230 total sample consisting of 46 cases and 184 controls. Subjects of this study were poor beneficiaries in Depok and North Jakarta 2 areas of Layanan Kesehatan Cuma-Cuma (LKC) Dompet Dhuafa. Results evidence first age of intercourse less than $<17$ years increased risk of pre-cancerous cervical lesions OR 4,092 (CI, 1,769-9,464), is mean women who had first intercourse less than <17 years had a risk of 4,092 times for the incidence of pre-cancerous lesions Cervix compared to women who had first intercourse more than $\geq 17$ years and also after controlled parity variables and hormonal contraception more than > 5 years. According to this study increased knowledge and understanding of risk factors for cervical cancer through education, control of marriage age and early detection with periodically checkup will reduce cases of pre-cancerous cervical lesions.
\end{abstract}

Keywords: Cervical Cancerous, Positive Visual Inspection With Acetic Acid 


\section{PENDAHULUAN}

Kanker leher rahim merupakan kanker nomer dua tersering diderita oleh perempuan di seluruh dunia dan penyebab kematian akibat kanker yang paling utama, khususnya bagi perempuan di Negaranegara berkembang. Berdasarkan data global cencer burden rises (GLOBOCAN) diketahui bahwa pada tahun 2012 terdapat 14.067.894 kasus baru kanker dan 8.201.575 kematian akibat kanker di seluruh dunia, dengan $70 \%$ kematian akibat kanker berada di negara miskin dan berkembang dengan insiden kanker meningkat dari 12,7 juta kasus tahun 2008 menjadi 14,1 juta kasus tahun 2012, dengan jumlah kematian meningkat dari 7,6 juta orang tahun 2008 menjadi 8,2 juta pada tahun 2012. ${ }^{1}$

Berdasarkan Pusat Data dan Informasi prevalensi kanker leher rahim di wilayah DKI Jakarta sebesar 1,2 dari 5.919 wanita yang melakukan skrining dan provinsi Jawa barat sebesar 0,7 dari 15.635 wanita. $^{2}$ Kanker leher rahim 99,7\% disebabkan oleh human papiloma virus (HVP) onkogenik, yang menyerang leher rahim. Sebelum terjadinya kanker leher rahim akan didahului dengan keadaan yang disebut lesi prakanker. ${ }^{3}$ Menurut Badan Pusat Statistik (BPS) pada tahun 2010 menunjukkan jumlah wanita Indonesia yang berusia 30-50 sampai dengan tahun 2012 dari 575.503 orang telah melakukan skrining inspeksi visual asam asetat (IVA), terdapat 25.805 orang dengan hasil IVA positif atau sekitar 4,5\% mengalami IVA positif. ${ }^{4}$

Inspeksi visual asam asetat (IVA) merupakan salah satu cara skrining kanker leher rahim yang mudah dilakukan dan memberikan hasil yang segara kepada ibu. Tujuan tes IVA untuk melihat adanya sel yang mengalami displasia sebagai salah satu metode skrining kanker mulut rahim. ${ }^{5}$

Pada dasarnya faktor risiko lesi pra kanker dan kanker leher rahim adalah sama. ${ }^{13}$ Ada beberapa faktor yang menyebabkan lesi prakanker dengan cepat menimbulkan kanker yaitu faktor individu, faktor risiko dan faktor pasangan. Faktor individu seperti HPV, etiologi, herpes simpleks, merokok, usia, paritas, menikah dan usia muda. Faktor risiko yaitu status gizi, gangguan sistem kekebalan, pengunaan pil $\mathrm{KB}$, ras, polusi udara, pemakian Dietilstilbesterol (DES) dan status ekonomi. Faktor pasangan yaitu hubungan seks pada usia muda dan pasangan seksual lebih dari satu (Multipatner Seksual). ${ }^{6}$ Diantara beberapa faktor yang menimbulkan kanker leher rahim ada faktor utama yang bisa mempercepat terjadinya infeksi HPV dan lesi prakanker leher rahim 
yaitu aktivitas seksual usia dini. 7 Berdasarkan penelitian sebelumnya menyatakan bahwa wanita yang memulai hubungan seksual pada usia $<17$ tahun memiliki risiko 2,539 kali terkena lesi prakanker dibandingkan mereka yang memulai hubungan seksual $\geq 17$ tahun. ${ }^{8}$

LKC Dompet Dhuafa merupakan NGO (Non Governmental Organization) yang salah satu untuk mengurangi permasalahan dibidang kesehatan melalui program ungguan kesehatan reproduksi dengan sasaran masarakat yang kurang mampu. Berbagai karakteristik masyarakat dan permasalahan kesehatan pada masyarakat di wilayah kerja LKC dompet Dhuafa salah satunya tentang lesi prkanker leher rahim.Temuan kasus kematian salah satu ibu akibat kanker leher rahim dengan stadium akhir, usia menikah $<20$ tahun masih tinggi, pendidakan, status ekonomi yang rendah dan kurangnya informasi khususnya tentang faktor risiko kanker leher rahim melatarbelakangi kejadian di atas.

Adanya temuan kasus kematian akibat kanker leher rahim, karakteristik panerima manfaat yang kurang mampu dengan faktor resiko usia menikah dini yang masih tinggi, maka peneliti tertarik menggambarkan faktor yang berhubungan dengan kejadian lesi prakanker leher rahim yaitu usia pertama kali berhubungan seksual pada penerima manfaat yang melakukan skrining kanker leher rahim dengan metode IVA di wilayah kerja Dompet Dhuafa tahun 2016.

\section{METODE}

Penelitian ini menggunakan data sekunder yang diambil dari rekam medis hasil pemeriksaan kanker leher rahim dan kanker payudara dengan metode Inspeksi visual Asam Asetat (IVA) di wilayah kerja Layanan Kesehatan Cuma-Cuma Dompet Dhuafa dari buan Mei s/d Oktober 2016. Studi ini menggunakan pendekatan kasus kontrol yang merupakan rancangan yang mempelajari hubungan antara paparan (faktor penelitian) dan penyakit, dengan cara membandingkan kelompok kasus dan kelompok kontrol berdasarkan status paparannya. ${ }^{9}$ Populasi penelitian ini adalah penerima manfaat LKC Dompet Dhuafa yang melakukan pemriksaan kanker leher rahim dengan metode IVA sebesar 550 dan bisa dilakukan analisis. Terdapat data missing sebanyak 17 dan terdapat 96 penrima manfaat sudah menopus $>50$ tahun.

Penghitungan besar sampel dalam penelitian ini, menggunakan rumus uji dua proporsi. Dari perhitungan didapatkan jumlah sampel minimal kasus sebanyak 86 
orang. Dengan perbandingan 1:1 didapatkan 86 kasus dan 86 kontrol. Jumlah kasus IVA positif di wilayah kerja LKC Dompet Dhuafa tahun 2016 sebesar 46. Untuk mencukupi hal tersebut peneliti meningkatkan kontrol sebesar 4 kali dengan perbandingan kasus 1:4. Jadi kelompok kasus diambil 46 dan kelompok kontrol adalah sebanyak 184 sehingga total sampel yang diambil sebanyak 230 sampel.

Variabel yang akan dilihat adalah kejadian lesi prakanker leher rahim (dependen) dan usia pertama kali berhubungan seksual (independen), selain itu diteliti pula variabel yang lain (kovariat) meliputi variabel umur, paritas, riwayat kanker keluarga, tahun, jumlah pasangan, terpapar asapa rokok > 1 jam sehari, status

\section{HASIL}

1. Wilayah Kejadian Lesi Prakanker Leher Rahim

Penerima manfaat dari Depok yang mengalami IVA postif sebanyak 32 orang dan IVA negatif sebanyak 116 sedangkan di wilayah Jakarta utara yang mengalami IVA postif sebanyak 14 orang dan IVA negatif 68 orang.

Tabel 1.Distribusi Kasus Kontrol Berdasarkan Wilayah Kerja dengan Kajadian Lesi Prakanker Leher Rahim gizi dan kontasepsi hormonal > 5). Analisis yang digunakan

adalah analisis regresi logistik.Penelitian ini menggunakan ukuran asosiasi OR karena kejadian Lesi prakanker leher rahim merupakan kejadian yang masih jarang (prevalensi $<10 \%$ ).

Penelitian ini dilaksanakan atas dasar persetujuan dari Komite Etik Fakultas Kesehatan Masyarakat Universitas Indonesia. Data yang diambil sudah atas izin dari Direktur LKC Dompet Dhuafa. Semua data yang dikumpulkan dalam penelitian ini hanya digunakan untuk keperluan ilmiah. Kode dan identitas subjek penelitian, sangat dirahasiakan untuk umum.

Pada Penerima Manfaat LKC Dompet Dhuafa Tahun 2016

\begin{tabular}{|c|c|c|c|c|}
\hline \multirow[t]{2}{*}{ Wilayah } & \multicolumn{2}{|c|}{ Kasus } & \multicolumn{2}{|c|}{ Kontrol } \\
\hline & $\mathrm{n}$ & $\%$ & $\mathrm{~N}$ & $\%$ \\
\hline Depok & 32 & 69,6 & 116 & 63 \\
\hline $\begin{array}{c}\text { Jakarta } \\
\text { Utara }\end{array}$ & 14 & 30,4 & 68 & 37 \\
\hline
\end{tabular}

2. Proporsi Kejadian Lesi Prakanker Leher Rahim Menurut Variabel Usia Pertama Kali Berhubungan Seksual. 
Proporsi penerima manfaat yang melakukan hubungan seksual $<17$ tahun yang mengalami kejadian IVA positif sebesar $39,1 \%$ dan yang hasil IVA negatif sebesar 10,3\%.

Tabel.2 Distribusi Kasus Dan Kontrol Berdasarkan Usia Pertama Kali Berhubungan Seksual $<17$ tahun Pada Penerima Manfaat LKC Dompet Dhuafa Tahun 2016

\begin{tabular}{lcccc}
\hline Usia & \multicolumn{2}{c}{ Kasus } & \multicolumn{2}{c}{ Kontrol } \\
\cline { 2 - 5 } & $\mathrm{N}$ & $\%$ & $\mathrm{n}$ & $\%$ \\
& 18 & 39,1 & 19 & 10,3 \\
$\begin{array}{l}\text { tahun } \\
\geq 17\end{array}$ & 28 & 60,9 & 165 & 89,7 \\
tahun & & & & \\
\hline
\end{tabular}

3. Proporsi Kejadian Lesi Prakanker Leher Rahim Menurut Variabel Lain

Proporsi kejadian lesi prakanker leher rahim lebih banyak pada kelompok kasus yaitu pada usia > 35 tahun sebesar 76,1\% dibandingkan kelompok kontrol sebesar $66,8 \%$. Penerima manfaat ditemukan memiliki paritas $\geq 4$ lebih besar pada kelompok kasus sebesar 43,8\% dan kelompok kontrol sebesar $12,5 \%$. Penerima manfaat dengan Jumlah perkawinan $>1$ pada kelompok kasus ditemukan sebesar $13 \%$ sedangkan pada kelompok kontrol sebesar 6,5\%. Status gizi dengan kategori berisiko pada kelompok kasus ditemukan sebesar $56,2 \%$ dan keompok kontrol sebesar $31 \%$. Terpapar asap rokok > 1 jam sehari ditemukan pada kelompok kasus sebesar 65,2\% dan kelompok kontrol sebesar 62,5\%. Riwayat kanker keluarga pada kelompok kasus ditemukan sebesar 6,5\% sedangkan kelompok kontrol sebesar 2,2\%. Penggunaan KB hormonal > 5 tahun ditemukan pada kelompok kasus lebih besar dibandingkan kelompok kontrol, kelompok kasus sebesar 56,5\% dan kelompok kontrol sebesar 19,5\%

Tabel 3. Kejadian Lesi Prakanker Leher Rahim Berdasarkan variabel lain Pada Penerima Manfaat LKC Dompet Dhuafa Tahun 2016 


\begin{tabular}{|c|c|c|c|c|}
\hline \multirow{3}{*}{ Variabel Covariat } & \multicolumn{4}{|c|}{ Lesi Prakanker Leher Rahim } \\
\hline & \multicolumn{2}{|c|}{ kasus } & \multicolumn{2}{|c|}{ Kontrol } \\
\hline & $\mathrm{N}$ & $\%$ & $\mathrm{~N}$ & $\%$ \\
\hline \multicolumn{5}{|l|}{ Usia } \\
\hline$\leq 35$ tahun & 11 & 23,9 & 61 & 33,2 \\
\hline$>35$ Tahun & 35 & 76,1 & 123 & 66,8 \\
\hline \multicolumn{5}{|l|}{ Paritas } \\
\hline$\geq 4$ & 16 & 43,8 & 23 & 12,5 \\
\hline$<4$ & 30 & 65,2 & 161 & 87,5 \\
\hline \multicolumn{5}{|l|}{ Jumlah Perkawinan } \\
\hline 1 & 40 & 87 & 172 & 95,3 \\
\hline$>1$ & 6 & 13 & 12 & 6,5 \\
\hline \multicolumn{5}{|l|}{ Status Gizi } \\
\hline$\leq 24,5$ (beresiko) & 26 & 56,5 & 57 & 31 \\
\hline$>24,5(\mathrm{tdk}$ beresiko $)$ & 20 & 43,5 & 127 & 69 \\
\hline \multicolumn{5}{|l|}{ Terpapar asap rokok > 1 jam sehari } \\
\hline $\mathrm{Ya}$ & 30 & 65,2 & 115 & 62,5 \\
\hline Tidak & 16 & 34,8 & 69 & 37,5 \\
\hline \multicolumn{5}{|l|}{ Riwayat kanker Keluarga } \\
\hline $\mathrm{Ya}$ & 3 & 6,5 & 4 & 2,2 \\
\hline Tidak & 43 & 93,5 & 180 & 97,8 \\
\hline \multicolumn{5}{|l|}{ Pengunaan KB Hormonal } \\
\hline$>5$ th & 26 & 56,5 & 36 & 19,6 \\
\hline Tidak & 20 & 43,5 & 148 & 80.4 \\
\hline
\end{tabular}

4. Hubungan usia pertama kali berhubungan seksual dengan kejadian lesi prakanker leher rahim

Berdasarkan analisis bivariat menunjukkan bahwa hubungan usia pertama kali berhubungan seksual $<17$ tahum dengan kejadian lesi prakanker leher rahim pada CI 95\% dan nilai $P$ value 0,000 secara signifikan menunjukkan bahwa terdapat hubungan yang bermakna antara usia pertama kali berhubungan seksual $<17$ tahun dengan kejadian lesi prakanker leher rahim pada penerima manfaat LKC Dompet Dhuafa, dimana penerima manfaat yang melakukan hubungan seksual $<17$ tahun memiliki resiko 5,583 untuk mengalami kejadian lesi prakanker leher rahim dengan 95\% CI (1.263 - 11,925).

Sedangkan berdasarkan analisis multivariat dengan menggunakan regresi logistik , didapatkankan OR adjust antara hubungan usia pertama kali berhubungan seksual dengan kejadian lesi prakanker leher rahim yaitu sebesar 4,092 (CI 1,769-9,464) artinya penerima manfaat dengan usia pertama kali berhubungan seksual $<17$ tahun memiliki resiko 4,092 kali untuk terjadi lesi prakanker lehe rahim dibandingkan penerima manfaat dengan usia pertama kali berhubungan seksual $>17$ setelah dikontrol variabel paritas dan $\mathrm{KB}$ hormonal. (lihat tabel 4) 
Tabel 4. Hubungan Usia usia pertama kali berhubungan seksual dengan kejadian lesi prakanker leher rahim Pada Penerima Manfaat LKC Dompet Dhuafa Tahun 2016

\begin{tabular}{|c|c|c|c|c|}
\hline \multirow{3}{*}{ Variabel Covariat } & \multicolumn{4}{|c|}{ Lesi Prakanker Leher Rahim } \\
\hline & \multicolumn{2}{|c|}{ kasus } & \multicolumn{2}{|c|}{ Kontrol } \\
\hline & $\mathrm{N}$ & $\%$ & $\mathrm{~N}$ & $\%$ \\
\hline \multicolumn{5}{|l|}{ Usia } \\
\hline$\leq 35$ tahun & 11 & 23,9 & 61 & 33,2 \\
\hline$>35$ Tahun & 35 & 76,1 & 123 & 66,8 \\
\hline \multicolumn{5}{|l|}{ Paritas } \\
\hline$\geq 4$ & 16 & 43,8 & 23 & 12,5 \\
\hline$<4$ & 30 & 65,2 & 161 & 87,5 \\
\hline \multicolumn{5}{|l|}{ Jumlah Perkawinan } \\
\hline 1 & 40 & 87 & 172 & 95,3 \\
\hline$>1$ & 6 & 13 & 12 & 6,5 \\
\hline \multicolumn{5}{|l|}{ Status Gizi } \\
\hline$\leq 24,5$ (beresiko) & 26 & 56,5 & 57 & 31 \\
\hline$>24,5$ (tdk beresiko) & 20 & 43,5 & 127 & 69 \\
\hline \multicolumn{5}{|l|}{ Terpapar asap rokok > 1 jam sehari } \\
\hline Ya & 30 & 65,2 & 115 & 62,5 \\
\hline Tidak & 16 & 34,8 & 69 & 37,5 \\
\hline \multicolumn{5}{|l|}{ Riwayat kanker Keluarga } \\
\hline $\mathrm{Ya}$ & 3 & 6,5 & 4 & 2,2 \\
\hline Tidak & 43 & 93,5 & 180 & 97,8 \\
\hline \multicolumn{5}{|l|}{ Pengunaan KB Hormonal } \\
\hline$>5$ th & 26 & 56,5 & 36 & 19,6 \\
\hline Tidak & 20 & 43,5 & 148 & 80.4 \\
\hline
\end{tabular}

* Setelah dikontrol dengan variabel paritas dan KB hormonal

\section{PEMBAHASAN}

Seperti dijelaskan sebelumnya, penelitian ini merupakan analisis data sekunder, tidak semua variabel kovariat diteliti, walaupun sudah dilakukan pengontrolan dengan menggunakan analisis multivariat, kemungkinan masih kurang dapat menjelaskan secara menyeluruh tentang faktor risiko lain yang terkait dengan hubungan usia pertama kali berhubungan seksual dengan kejadian lesi prakanker leher rahim. Berdasarkan penelitian sebelumnya, menyebutkan adanya hubungan yang bermakna usia pertama kali berhubungan seksual < 17 tahun dengan kejadian lesi prakanker leher rahim dengan OR 2,539. Selain faktor usia berhubungan seksual, faktor sosial ekonomi rendah memiliki resiko dengan kejadian lesi prakanker leher rahim. ${ }^{11}$ Penelitian yang dilakukan di India dengan melihat faktor resiko yang berhubungan dengan kejadian kanker leher rahim ditemukan bahwa faktor resiko usia menikah $<18$ tahun memiliki resiko dan status ekonomi rendah memiliki resiko kejadian kanker leher rahim dengan masing-masing OR usia menikah < 18 
tahun sebesar 1,93 (1,271-2,798) dan status ekonomi rendah dengan OR 1,39 CI 1,0311,762). Dapat disimpulkan bahwa usia pertama kali berhubungan seksual $<17$ tahun dan status ekonomi rendah memiliki resiko terjadinya lesi prakanker leher rahim.

Semakin muda usia melakukan hubungan seksual pertama kali mempengaruhi besarnya resiko lesi kanker leher rahim. Sel-sel mukosa baru matang setelah wanita berusia 20 tahun ke atas. Jadi, seorang wanita yang menjalin hubungan seks pada usia remaja, paling rawan bila dilakukan di bawah usia 17 tahun. Hal ini berkaitan dengan kematangan sel-sel mukosa pada serviks. Pada usia muda, sel-sel mukosa pada serviks belum matang. Artinya, masih rentan terhadap rangsangan. Sehingga tidak siap menerima rangsangan dari luar. Termasuk zat-zat kimia yang dibawa sperma. Karena masih rentan, sel-sel mukosa bisa berubah sifat menjadi kanker. Sifat sel kanker selalu berubah setiap saat yaitu mati dan tumbuh lagi. Dengan adanya rangsangan, sel bisa tumbuh lebih banyak dari sel yang mati, sehingga perubahannya tidak seimbang lagi. Kelebihan sel ini akhirnya bisa berubah sifat menjadi sel kanker. ${ }^{10}$

Kejadian lesi prakanker tidak luput dari faktor prilaku. Prilaku sehat dapat terbentuk karena adanya berbagai pengaruh atau rangsangan yang berupa pengalaman, keyakinan, sosial, budaya dan saran fisik. Pengaruh rangsangan bisa bersifat internal dan ekternal dan dikasifikasikan menjadi faktor predisposisi, faktor pemungkin dan faktor pendorong. Faktor pendorong salah satunya kurangnya pemahaman masyarakat tentang kanker leher rahim karena minimnya gejala yang ditimbulkan oleh kanker leher rahim maka penanganan terhadap penyakit sering kali terlambat yang mengakibatkan kematian. Berdasarkan temuan kasus kematian salah satu ibu akibat kanker leher rahim di salah satu wilayah sasaran LKC Dompet Dhuafa tepatnya di wilayah Depok yang di temukan sudah dengan stadium akhir. Hal ini membuktikan bahwa masyarakat masih kurang memahami baik faktor resiko maupun tanda dan gejala tantang kanker leher rahim. hal lain yang turut mempengaruhi kejadian kanker leher rahim adalah skrining kesehatan. Skrining kesehatan seperti IVA dan Papsmear masih belum dianggap suatu kebutuhan oleh para wanita sehingga cakupan skrining hanya 5 $\%$.

Faktor pemungkin yang berhubungan dengan kejadian lesi prakanker leher rahim yaitu kesadaran wanita dalam melakukan IVA atau Papsmear maupun vaksinasi virus Human 
Papiloma Virus (HPV) disebabkan karena berbagai faktor sosial ekonomi rendah. Kemiskinan mengakibatkan ketidakmampuan mereka untuk mendapat pelayanan kesehatan yang baik dan tidak dapat membayar biaya-biaya tes kesehatan yang cukup mahal. ${ }^{12}$

Salah satu faktor pemungkin kejadian lesi prkanker leher rahim salah satunya adalah faktor budaya. Budaya masih berperan penting seperti salah satu budaya sebagai contoh upacara adat di papua yang menghendaki adanya hubungan seksual secara berramai-ramai. Hal-hal berkenan dengan sosial budaya masyarakat merupakan hal yang paling sulit diubah.

Faktor pendorong yang berkaitan dengan kejadian lesi prakanker leher rahim yaitu faktor yang bersifat pelayanan untuk masyarakat seperti kesiapan tenaga kesehatan yang berkecimpung dalam program penapisan kanker leher rahim dan peralatan yang ada di instansi tersebut. Selain faktor- faktor yang bersifat pelayanan sikap dan prilaku wanita seperti asupan makanan, aktivitas seksual, penggunaan $\mathrm{KB}$ hormonal jangka panjang yang merupakan faktor resiko terjadinya lesi prakanker leher rahim.

Hasil yang didapatkan dalam penelitian tersebut, kemungkinan masih dipengaruhi oleh adanya bias seleksi apabila dilihat dari aspek diantaranya proses pemilihan populasi penelitian, penggunaan desain kasus kontrol dan adanya missing data (data sekunder). pengambilan data berasal dari penerima manfaat ynag dengan suka rela memeriksakan diri untuk melakukan skrining dengan metode IVA hal tersebut dapat menjadikan bias sukarelawan (volunteer bias) yaitu bias yang disebabkan kesukarelawan responden untuk berpartisipasi, kesukarelaannya tersebut berhubungan dengan status penyakit dan status paparan sehingga dapat memperbesar (overestimate) atau memperkecil (underustimet) hubungan paparan dan penyakit yang sesungguhnya.

Selain dipengaruhi adanya bias seleksi, penelitian ini juga masih dipengaruhi adanya bias informasi. Bias recall dapat terjadi pada penelitian ini karena daya ingat penerima manfaat yang berbeda satu sama lain terkait faktor resiko yang berhubungan dengan kajadian lesi prakanker leher rahim seperti penggunaan KB hormonal dan terapapar asap rokok $>1$ jam sehari yang ada dikuesioner. Bias informasi juga dapat terjadi pada variabel usia pertama kali berhubungan seksual dan jumlah pasangan. Keakuratan data data sangat tergantung kejujuran penerima manfaat dalam menjawab pertanyaan yang ada di kuesioner. Bias misklasifikasi non diferensial dapat terjadi terkait dengan 
metode skrining kanker leher rahim yang digunakan dengan menggunakan metode IVA. Sensitifitas IVA hamipr sama dengan tes Papsmear namun spesipisitasnya lebih rendah daripada test papsmear sehingga nilai predikitif negatif lebih tinggi pada orang yang melakukan IVA dibandingkan dengan melakukan tes Papsmear. Misklasifikasi nondiferensial dapat menyababkan besar asosiasi yang diperoleh menjadi underestimate/mendekati null value .

Pada penelitian ini dapat digeralisasikan hanya ke populasi studi dengan alasan bahwa sampel yang diambil dilakukan dengan cara rendom sampling sehingga mewakili populasi studi yakni Penerima manfaat dan atau telah menikah diwilayah kerja LKC Dompet Dhuafa. Penelitian ini juga dapat digeralisasi ke populasi target yakni peneriama manfaat yang telah menikah dengan karakteristik yang sama dengan sampel.

\section{KESIMPULAN}

Berdasarkan hasil penelitian dan pembahasan yang telah diuraikan, proporsi penerima manfaat. Proporsi penerima manfaat yang melakukan hubungan seksual $<17$ tahun yang mengalami kejadian IVA positif sebesar $39,1 \%$ dan yang yang mengalami hasil IVA negatif sebesar 10,3\%. Didapatkan hasil adanya hubungan yang bermakna hubungan usia pertama kali berhubungan seksual $<17$ tahun dengan kejadian lesi prakanker leher rahim setelah dilakukan kontrol nilai $\mathrm{P}$ value 0,001 dan OR 4,092 (CI,1,769-9,464) yang berati bahwa risiko terkena lesi praprakanker leher rahim pada penerima manfaat yang memulai hubungan seksual $<17$ tahun adalah 4,092 kali lebih tinggi dibanding mereka yang memulai hubungan seksual $>17$ tahun. Setelah dilakukan kontrol terhadap variabel kovariat terbukti tidak ada interaksi namun ada konfounding yaitu variabel paritas dan KB hormonal. Mengingat besarnya faktor resiko dengan kejadian lesi prakanker diperukan upaya peningkatan karenanya peningkatan pengetahuan dan pemahaman tentang faktor resiko kanker leher rahim melalui edukasi, pendewasaan usia pernikahan serta deteksi dini melalui pemeriksaan rutin akan membantu mengurangi kasus lesi prakanker leher rahim.

Selain itu perlunya penambahan pada instrumen pengukuran (kuesioner). Karena ada beberapa faktor risiko yang tidak diukur dengan ukuran standar diantaranya pendidikan. Oleh karena itu, perlu dilaksanakan penelitian lanjutan dengan desain yang lebih baik, sampel yang lebih besar dan mengunakan alat ukur atau ukuran yang standar serta perlu 
penambahan variabel penelitian yang belum diteliti.

\section{DAFTAR PUSTAKA}

1. World Health Organization. (2013). Cervical Cancer Screening In Developing Countries : Report Of A WHO Consultation. Geneva: WHO.

2. Pusdatin, 2013, Situasi Penyakit Kanker. Diunduh Dari Http://Www. Depkes.Go.Id/Resources/Download/P usdatin/Infodatin/Infodatin-

Kanker.Pdf Diakes Pada Tanggal 16 Juni 2017

3. Andi DP, Endy MM, 2006. Lesi prakanker serviks. Yayasan Bina Pustaka Sarwono Prawirohardjo, Jakarta

4. Depkes, 2012, Skrining Kanker Leher Rahim Dengan Metode Inspeksi Visual Dengan Asam Asetat (IVA),Dirjen PTM, Jakarta

5. Depkes RI. 2009. Deteksi Dini Kanker leher Rahim dan kanker payudara, Ditjen PP \&PL, Jakarta

6. Diananda, R., 2009. Kanker Serviks: Sebuah Peringatan Buat Wanita. In: Diananda, R. Mengenal Seluk-Beluk Kanker, Katahari, Yogyakarta

7. Shinta. 2010, Kanker Servix Dan Infeksi Human Papiloma Virus (HPV), Javamedika Network, Jakarta.
8. Indi, 2010, Hubungan Peratama Kali Berhubungan Seksual Dan Jumlah Pasangan Seksual Dengan Kejadian Lesi Pra Kanker Leher Rahim Pada Wanita Yang Melakukan Deteksi Dini Menggunakan Metode IVA Di Puskesmas Cikampek, Pedes Dan Kota Baru Kabupaten Kerawang Tahun 2009-2010. Thesis Fakultas Kesehatan Masyarakat Universitas Indonesia.

9. Murti Bhisma. 1997, Prinsip Dan Metode Riset Epidemiologi, Gajah Mada University Press.

10. Irianto Koes. 2015, Kesehatan Reproduksi (Reproductive Health) Teori dan Praktikum, Alfabeta, Bandung.

11. Sukaca, S. 2009, Cara Cerdas Menghadapi Kanker Servik. Yogyakarta:Genius Printika

12. Nurwijaya, H., Et Al., 2010. Cegah Dan Deteksi Kanker Serviks, PT. Gramedia, Jakarta.

13. Andrijono, 2013, Sinopsis Kanker Ginekologi. Pustaka Spirit, Jakarta. 